\title{
Influence of Adhesives Storing Temperature on Adhesive Bond Strength
}

Miroslav Müller

Faculty of Engineering, Department of Material Science and Manufacturing Technology, Czech University of Life Sciences in Prague. Kamýcka 129, 16521 Praha - Suchdol. Czech Republic. E-mail: muller@tf.czu.cz

Adhesive bonds are very often applied in various climatic conditions and environments. Each environment is of specific properties which basically influence entire strength and reliability of an adhesive bond. The influence of the surroundings temperature on the strength and service life of the adhesive bond is one of the most important factors which has to be taken into regard by a designer when designing the bond. However, during a transit or a storing the adhesives can meet much higher or lower temperatures than it is recommended by a producer. The aim of the experimental part is a determination of the influence of the storing temperature in the interval -20 to $100{ }^{\circ} \mathrm{C}$ on the resultant strength of the adhesive bond. Two-component epoxy and acrylate adhesives which are used as the constructional ones were used for experiments. The subject of the research was the adhesives which are not specially determined for using in high or low temperatures. From the results it is obvious that the packing type is essential for a transfer of surroundings temperature into the adhesive. Higher storing temperatures (temperatures exceeding $60^{\circ} \mathrm{C}$ ) affect in a negative way the adhesive bond strength.

Keywords: adhesive bonding technology, packing, strength, surroundings temperature

\section{Acknowledgment}

Supported by Internal grant agency of Faculty of Engineering, Czech University of Life Sciences in Prague.

\section{References}

[1] MÜLLER, M., VALÁŠEK, P. (2012). Degradation medium of agrokomplex - adhesive bonded joints interaction. In: Research in Agricultural Engineering, Vol. 58, No. 3, pp. 83-91.

[2] MÜLLER, M. (2013). Research of liquid contaminants influence on adhesive bond strength applied in agricultural machine construction, In: Agronomy Research, Vol.11. No.1, pp. 147 - 154.

[3] NOVÁK, M. (2012). Surfaces with high precision of roughness after grinding. In: Manufacturing technology, Vol. 12, No.12, pp. 66 - 70.

[4] NOVÁK, M. (2011). Surface quality of hardened steels after grinding. In: Manufacturing technology, Vol. 11, No. 11, pp. 55 -59 .

[5] NESLUŠAN, M., ROSIPAL, M., KOLAŘIK, K., OCHODEK, V. (2012). Application of barkhausen noise for analysis of surface integrity after hard turning. In: Manufacturing technology, Vol. 12, No. 11, pp. 60-65.

[6] HOLEŠOVSKÝ, F., NÁPRSTKOVÁ, N., NOVÁK, M. (2012). GICS for grinding process optimization, In: Manufacturing technology, Vol. 12, No. 1, pp. 22-26.

[7] MÜLLER, M., VALÁŠEK, P. (2013). Comparison of variables influence on adhesive bonds strength calculations, In: Manufacturing technology, Vol. 13, No. 2, pp. 205 - 210.

[8] MÜLLER, M., HŮRKA, K. (2006). Vliv teploty prostředí na dobu vytvrzování lepidla v lepeném spoji. In: Strojírenská technologie, Vol. 12, No. 1, pp. 9 - 15.

[9] MESSLER, R. W. (2004). Joining of materials and structures from pragmatic process to enabling technology. Pp. $815 \mathrm{pp}$. Burlington: Elsevier.

[10] MÜLLER, M. (2011). Proces stárnutí a trvanlivosti garantované výrobcem na hodnocení lepených spojů. In: Strojírenská technologie, Vol. 16, No. 2, pp. 23 - 28.

[11] MÜLLER, M., BROŽEK, M. (2005). Technologie lepení - vliv expirační doby lepidel na pevnost lepených spojů. In. Strojírenská technologie, Vol. 10, No. 3, pp. 10 - 16.

[12] ČSN EN 1465: Adhesives - Determination of tensile lap-shear strength of bonded assemblies. Prague, Czech Standard Institute, 1997. (In Czech)

[13] NOVÁK, M., KASUGA, H., OHMORI, H. (2013). Differences at the surface roughness by the ELID and grinding technology, In: Manufacturing technology, Vol. 13, No. 2, pp. 210 - 215.

[14] COURT, R., SUTCLIFFE, M., TAVAKOLI, S. (2001). Ageing of adhesively bonded joints - fracture and failure analysis using video imaging techniques. In: International Journal of Adhesion \& Adhesives, Vol. 21, No. 6, pp. 455 - 463. 